\title{
Thinking Development: African Culture and Sustainable Water Management
}

\author{
Akowanou Clément Ahouandjinou ${ }^{1 *}$, Cheikh Ibrahima Niang1, Abdoulaye Sene ${ }^{2}$ \\ ${ }^{1}$ SAHARA Laboratory, Inst. of Envi. Sciences Cheikh Anta DIOP University, Dakar, Senegal \\ ${ }^{2}$ UER/EGDD, Inst. of Envi. Sciences Cheikh Anta DIOP University, Dakar, Senegal \\ Email: *akowcle@yahoo.fr
}

How to cite this paper: Ahouandjinou, $\mathrm{A}$ C., Niang, C. I., \& Sene, A. (2020). Thinking Development: African Culture and Sustainable Water Management. Open Journal of Philosophy, 10, 331-345.

https://doi.org/10.4236/ojpp.2020.103022

Received: June 26, 2020

Accepted: August 8, 2020

Published: August 11, 2020

Copyright (c) 2020 by author(s) and Scientific Research Publishing Inc. This work is licensed under the Creative Commons Attribution International License (CC BY 4.0).

http://creativecommons.org/licenses/by/4.0/

(c) (i) Open Access

\begin{abstract}
This article is intended to be a contribution to the discussion on culture and development, the central place that culture must occupy at the heart of development. Criticism of the concept of sustainable development has shown that it does not integrate culture. This discussion is applied in this study to the rural water sector in Africa, which is a key sector of development. Thus, the articulation of culture and sustainable development in the water sector has three aspects. That the local culture of beneficiaries of hydraulic structures providing access to drinking water be taken into account for an economically viable, socially equitable and ecologically viable management and that future generation can benefit from it.
\end{abstract}

\section{Keywords}

Culture, Sustainable Development, Water, Management, Ethics, Environment

\section{Introduction}

This article is intended to be a contribution to the debate on the link between culture and development, an articulation between culture and sustainable development in Africa in the rural hydraulics sector, access to drinking water. Some people put forward the idea that the failure of public policies in Africa is due to the disregard of the local cultures of the populations that benefit from development works. Thus, for Diop, in the eyes of some Africanist researchers, "the failure of development in other cultures, particularly in Africa, is due to the failure to take into account the cultural factors of African societies in developmentist strategies" (Diop, 2016: pp. 109-110). As for Mboua, "Africa's failure is not a fatality but a process. It is because our societies have not made certain internal changes in the course of their historical processes that they do not meet 
the requirements of modern societies" (Mboua, 2014: p. 12).

This contribution focuses on the rural hydraulics sector in Africa. And the question is: how can traditional local culture be articulated for the sustainable management of hydraulic works for access to drinking water in Africa? This reflection observes three moments. First, for the reference framework, the concepts of African culture and sustainable development will be presented and their interconnections discussed. Then, culture will be highlighted in the three dimensions of sustainable development: economic, social and environmental. Finally, participation will be made in the discussion concerning the articulation between culture and development in the water sector in Africa.

\section{Culture and Development}

\subsection{African Culture, an Asset for Development}

UNESCO experts affirming cultural identity define culture as follows. "Culture is the totality of the deeds and actions of a group of people; it is the way in which they conceive, organize and conduct their daily and millenary existence; (...) Culture is all that by means of which and through which man exists and subsists, it is the arsenal of technical and mystical means which ensure life and survival for man and the group" (Etounga-Manguelle, 1993: p. 39). For Mboua, "the way in which we consider human beings and the vision we have of their fulfilment determine the meaning and content of development for progress". As he shows, "African cultures have assets for development for progress: solidarity, hospitality, co-responsibility and environmental protection, to name but a few" (Mboua, 2014: p. 67). Although African culture is an asset for development, it is marked like all other cultures by limitations that need to be remedied. According to Mboua's explanation, "Individualism and selfishness are scourges that are on the increase". This manifests itself in prevarication, corruption, illicit enrichment. These factors weaken the fundamental values of the common good, hospitality, sharing and solidarity. African culture, like all others, has its strengths and weaknesses. Its shortcomings must be remedied if African culture is to be a genuine driving force for development. In this sense, according to the explanation of Mboua, "individualism and selfishness are scourges that are on the increase. This manifests itself through prevarication, corruption, illicit enrichment. These factors weaken the fundamental values of the common good, hospitality, sharing and solidarity" (Mboua, 2012: p. 207). For him, "The question that arises is whether it is possible to achieve development for progress without changing mentality and social structures? In other words, is it possible to achieve development for progress without surpassing oneself?" (Mboua, 2014: p. 11).

In the same vein, Etounga-Manguelle, speaking of the flaws in African culture today, explains, "Africa can be seen and felt through certain scenes of daily life: the nonchalance of the crowd wandering through the streets of the cities; people lying down in the middle of the day, taking a rest in front of their houses; (...) the weight of superstition in the mentalities of your interlocutors" (Etounga-Manguelle, 
1993: p. 38). He also wonders: "How can a person who has to take care of ten or twenty people with his meagre salary be included in development?" (Etounga-Manguelle, 1993: p. 12). But then what kind of development is Etounga-Manguelle talking about? Taking African culture into account is the condition for development. Mboua shows that "Traditional African cultures offer a rich content that makes it possible to pursue development for progress". They comprehend development from a social and community point of view rather than from an individual point of view, because what is important is to protect the group rather than the individual. For him, "the person cannot find his or her own fulfillment solely within himself or herself, that is, independently of his or her being 'with' and 'for' others. Such a conception leads everyone to value and commit oneself to the development of the common good" (Mboua, 2014: p. 63).

Culture is the essence of a people. The development of peoples is only possible if their culture is taken into account. According to Bujo, "The foundations of African anthropology are resistant to modernity and should, therefore, constitute the soul of any development programme in sub-Saharan Africa". As he shows, "African economic life is also often determined, at least implicitly, by the cultural background of the ancestors. It is here that what Verena Tobler Müller (1997) calls 'core culture' (Kernkultur) needs to be dissected. The 'core culture' generally refers to the cultural functions, structures and codes that, in a given society, are perceived as essential for the survival of its members". As he explains, "all the measures that development agencies advocate to improve the situation of African countries will remain ineffective if their 'core culture' is ignored". According to the author, "It is imperative that technological and economic practices address all the cultural elements of African peoples. They must take into account and integrate not only the visible structures, institutions and rules of society, but also the symbols, rituals, myths and other non-visible elements that serve to interpret the world and guide people" (Bujo, 2007: p. 45). This presentation of culture in general and African culture in particular invites us to reexamine the notion of sustainable development.

\subsection{Sustainable Development, an Evolving Concept}

The concept of sustainable development was born in the intimacy of IUCN reports in 1980. IUCN used the term sustainable development in 1980 in a book entitled World Conservation Strategy. The concept came to the international stage in 1987 with the "Brundtland Report" (Pellaud, 2011: p. 11). However, it was not until 1992 and the United Nations conference in Rio that the concept appeared, more and more regularly, in the non-specialized media. It must be said that the idea that was conceptualized in the term sustainable development predates the year 1980. This idea was already supported by great thinkers such as Edgar Morin or Joël de Rosnay in their books published in the 1970s. And, if no terminology was used at that time to put on the same balance economy, ecology and social development, the Stockholm conference in 1972 was already funda- 
mentally oriented towards these interactions. In another order, the Club of Rome already in 1972 entitled “Stop Growth?" in a report that raised the delicate problem of population growth coupled with that of economic growth (Meadows, Meadows, Randers, \& Behrens, 1972).

Pellaud writes: "afin to make sustainable development a real tool for thinking about a liveable and equitable future, we emphasize the fact that this concept is above all a search for balance that must be achieved through regulation" (Pellaud, 2011: p. 15).

Thus it is no longer a question of regulating the environment, as has been the case since animal domestication and the development of agriculture, but rather of regulating human activities and development. However, if for ethical reasons the problem of population growth is not frankly addressed, as Maltus had already raised, it is nevertheless an integral part of a balance that must be found (Pellaud, 2011: p. 15).

Pellaud argues that the perspective of regulation as a necessity for sustainable development is close to the thinking of John-Stuart Mill (Mill, 1953). The latter had already pointed out that the stability of population and wealth does not imply the immutability of human progress. This perspective is based both on the idea that, if we really want to achieve a better distribution of wealth, we must stop plundering it, and on that of technological progress, provided that it is aimed at the "best" and not the "most" (Pellaud, 2011: p. 19). As Pellaud shows, "This dynamic also means that the concept itself is constantly evolving" (Pellaud, 2011: pp. 53-54).

In 2002, on the occasion of the Johannesburg Summit, Edgar Morin wrote: "Should we not get rid of the term development, even if it is amended or softened to sustainable, sustainable or human development?" (Morin, 2002). For the latter, the idea of development has always had a technical-economic basis, measurable by growth and income indicators. It implicitly assumes that "techno-economic development is the locomotive that naturally leads to 'human development', whose accomplished and successful model is that of countries considered to be developed, in other words, Western countries" (Morin, 2002). And in the same vein, Sylvain Allemand points out that "much more than a turnkey solution, sustainable development is part of a process of innovation that is both technical and social. As a result, it has little or nothing to do with what it might have been twenty years ago, even if its finalités has remained the same" (Allemand, 2007).

Evolution of the concept of sustainable development:

There is an official definition of the concept of sustainable development, that of the Brundtland Report, namely: "development that meets the needs of the present without compromising the ability of future generations to meet their own needs". Commenting on this definition, Allemand points out that, to be generous, such a definition does not prove to be as operational as its proponents expected, nor does it "speak volumes". First of all, it emphasizes responsibility towards future generations, where present generations have a legitimate concern 
for their own fate, in the countries of the South even more than in the countries of the North. Secondly, it reduces sustainable development to three pillars (economic, environmental and social), while seeming to forget the cultural (diversity of world views, languages, preservation of the heritage inherited from past generations) and political (democracy, definition of a new governance) issues. Since then, a profusion of definitions have been proposed, as if to make up for the shortcomings of the former, which has not been without generating a certain cacophony, some emphasizing environmental issues, other social issues (Allemand, 2007).

The evolution of the concept of sustainable development is also debated at the semantic level. We note the semantic quarrel, between theorists, over the choice of the qualifier: sustainable or sustainable (or still viable)? In a (sustainable) case, one does not give up on maintaining economic growth, while being more concerned than in the past with its effects on the environment and social cohesion. In the other (sustainable) case, we are concerned about the balance of the planet, even if it means curbing growth. And for Allemand, "While the definition of the Brundtland report remains a reference, the notion has in fact been significantly enriched by the lessons learned from experiences and theoretical contributions" (Allemand, 2007). In short, as Pellaud explains, "Sustainable development is not a closed system. It evolves in space and time, and the regulations resulting from its organisation, or producing it, cannot escape this spiral" (Pellaud, 2011: p. 53). It emerges that the idea of process is fundamental to the concept of sustainable development. The term sustainable or sustainable development can slow down or mitigate, but not change, the tendency to destruction. It is therefore not so much a question of slowing down or mitigating, but of designing a new beginning.

\section{Culture at the Heart of Sustainable Development in the Water Sector}

Applying the link between culture and development in the water sector, the question is posed in these terms. How to articulate African culture and sustainable development in the field of water management? In other words, how can culture be taken into account so that the management of hydraulic works for access to drinking water is economically livable, socially equitable and ecologically viable and benefits future generations?

\subsection{Economically Viable Management}

Given the cultural meaning of water, "water is life", the social dimension of water pricing must be highlighted. In this sense, Bujo argues that "Profitability should not be the first criterion, but the humanization of man in his cosmic dimension" (Bujo, 1992: p. 157). Water in local symbolism is the fruit of sacrifice, of the gift that people have made of themselves. And in the dynamics of giving, one cannot opt to sell water and even increase the price of water on the pretext that the profits will go into the municipal budget. You can't rely on social wel- 
fare to finance the running of an institution. Thus the commune must be able to find other sources of financing and not hope to make profits on water, which is life and which must be free. As Singleton shows, "A well where as many people as possible can come and draw for nothing the gift of water that God and/or Destiny has given to humanity, that is the ideal" (Singleton, 2010: p. 34). According to Singleton, "privatizations-on any scale-that benefit some, however small, would be far more ambiguous" (Singleton, 2010: p. 34). According to Singleton, "it is understandable that a not-for-profit co-operative would eventually take over the distribution of water; for a company to do so, not to provide a service but to make a profit, would be borderline reprehensible" (Singleton, 2010: p. 34). Thus, as Côté shows, "beyond the economic discourse, there are ethical arguments in favour of water accessibility: equity, intergenerational solidarity and social justice" (Côté, 2006: p. 63).

With regard to the economic management of hydraulic works for access to drinking water, three aspects should be highlighted. First, there is the cost of water from the identification of the resource to its distribution, then the price of water, which is lower than its cost, and finally the social dimension of water pricing, which ranges from reducing the price to making water free for the poorest.

The cost of water:

Water certainly has no price, it must be free. But its extraction, transport, conservation, treatment and distribution have a cost that must be paid for. As Payen argues, "Water itself, of course, is free in nature like fish in the sea. But it has to be pumped, purified and transported to its place of use with an industrial organisation that has to operate without fail 24 hours a day. All this has a cost, which is the cost of a service, that of delivering clean water to the home." (Payen, 2013: p. 132). The question is, who pays for these costs and at what level? The various stakeholders are consumers, the municipality, the State, donors, the economic operator and non-governmental organizations.

Components can be identified in the cost of water. According to Payen, "It is made up of two essential components: current operating costs on the one hand, i.e. the day-to-day running of the service; the costs related to the construction of infrastructures on the other hand, whether existing or under construction. The latter are depreciation charges and financial expenses. The two components have similar orders of magnitude" (Payen, 2013: p. 132). As Payen explains, "for services that function well and are capable of meeting the expectations of the entire population on a sustainable basis, this 'infrastructure' component generally represents between 50\% and 100\% of current operating costs" (Payen, 2013: p. 132). And as Payen points out, "The cost of the water service is the sum of the expenses paid by those providing the service, i.e. the public authority and its operator(s). It is calculated at the scale of the territory for which the authority is responsible" (Payen, 2013: pp. 132-133). As Richter explains, "there is a lot of expenditure related to the good management and governance of the water we all use, and we all have to contribute to financing these essential services" (Richter, 
2017: p. 72).

The need for money for the proper functioning of hydraulic infrastructures for access to drinking water is obvious. As Richter explains, "Money is needed to pay the water managers who work for the agencies that issue and administer water rights. Money is also needed to build and maintain the infrastructure to store and distribute water to users" (Richter, 2017: p. 64). Richter also notes that: "money is needed ... to fund computers that are used to create watershed and aquifer models and to store data that help water managers archive data on water rights and violations of those rights" (Richter, 2017: p. 64).

Furthermore, according to Richter, "Funding is essential to operate the scientific instruments and water level gauges that continuously monitor water availability and consumption" (Richter, 2017: p. 64). Whereas, as Richter notes, "the most widespread problem facing governments is lack of funding" (Richter, 2017: p. 64). And the consequences are detrimental to the management of water infrastructure. As Richter explains, "if government does not generate enough money from taxes or other means to meet these needs, or if government simply does not allocate enough resources for water governance, water allocation and management systems are almost certainly doomed to failure” (Richter, 2017: p. 64).

When we look at the management of water facilities, a diversity of sources of funding for these facilities emerges. For Payen, "The drinking water service set up by a public authority in a territory may receive funds of various kinds, such as bank loans or private investments, but, in the end, the revenues that balance the service's charges are of only three types: payments of water bills by users; public budgets funded by the territory's taxpayers; and donations of all kinds expressing solidarity with people who do not benefit from the service" (Payen, 2013: p. 134). According to Payen's explanation, "To identify them properly, economists in the sector call them the '3Ts' with a ' $\mathrm{T}$ ' for 'tariffs', a second for 'taxes' and a third for 'transfers' from outside" (Payen, 2013: p. 134). As Payen shows, "At the country level, the 3Ts include payments by users, contributions from taxpayers via public budgets as well as possible subsidies from the energy sector and donations from abroad. These consist mainly of international public aid, NGO funding and corporate sponsorship. The total of the 3Ts calibrates the economy of the water services sector" (Payen, 2013: p. 134).

For Payen, "pricing policy, the policy that sets different prices for different users, cannot be decided without taking fiscal policy into account" (Payen, 2013: p. 136). According to Payen, "If the public authority wants to finance a major physical investment to develop a water service that exactly balances its revenue and expenditure, it must find the regular supplement of revenue from tariffs or public budgets that will allow repayment over time" (Payen, 2013: p. 138). Thus, as Payen explains, "Apart from external aid, the cost of a water service is equal to the sum of the contributions of the population through tariffs and taxes. If tariffs are lowered, taxes must be increased. If public subsidies are reduced, tariffs must be increased. Tariffs are therefore the result of the choice that is made in the distribution of the total cost" (Payen, 2013: p. 135). 
Water prices:

A whole theory is built around the water tariff. The price of water at the local level is one of the elements used to assess the functioning of a municipality. As Payen shows, "Tariffs represent the visible part of the water service. Are they too high or too low? Is it normal for them to increase in some cases and why?" (Payen, 2013: p. 132). Thus, as Payen explains, "The price of water is what is paid by the user, the 'water tariff. The sum of these individual payments forms the turnover of the utility" (Payen, 2013: p. 133).

The water tariff is particularly appreciated by the consumer. According to Payen, "Consumers often complain about what they consider to be excessive tariffs. But do they really know how these are determined? Are they aware of the subsidies they receive? Does the public official seeking money from banks or investors to finance new infrastructure properly consider the consequences of such financing on the price of water? There are many pitfalls in saving water" (Payen, 2013: pp. 131-132).

Social dimension of pricing:

The social dimension can be seen in the pricing of water in relation to its real cost. For Payen, "Price is usually confused with the cost of drinking water. Contrary to public opinion, on average in the world, the price of water is much lower than its cost!" (Payen, 2013: p. 132). According to Payen's explanation, “There are two mechanisms by which the majority of users pay less than the average cost of drinking water in their locality. First, it is very rare that the utility's revenues are able to compensate for all costs. Even in developed countries, some of these costs are covered by subsidies from public budgets. In developing countries, it is much worse" (Payen, 2013: p. 133). As Payen points out, "it is estimated that more than $40 \%$ of operators have a turnover that does not even reach their operating costs! They can only subsist with balancing subsidies voted a posteriori" (Payen, 2013: p. 133). Thus in general, as Payen shows, "the price of water paid by the population is often lower than the real cost of the service" (Payen, 2013: p. 134).

Apart from the price of water, which is lower than its real cost, solidarity exists between large and small consumers. As Payen argues, "the policy of a single identical tariff for all users in the same locality is a minority policy in the world, rather reserved for rich countries" (Payen, 2013: p. 133). As Payen explains, "In the majority of developing countries, tariff schedules include several differentiated prices according to types of users or their consumption. This leads some users, such as businesses (Colombia) or large consumers, to subsidize other numerically more numerous users" (Payen, 2013: p. 133). Payen gives the example of Morocco. "In Tangiers, Morocco, a third of the inhabitants pay less per cubic metre of water than the operator pays to buy it from the company that purifies the water. Clearly, they do not contribute to the cost of construction or operation of the network. Other consumers pay the full cost" (Payen, 2013: p. 133). And the question arises, according to Payen: "Who pays the difference?" The answer is: "It's still the population; through a different channel: taxes. The cost 
of drinking water is therefore essentially covered by users and taxpayers" (Payen, 2013: p. 134).

It is true that water has a cost and has a price. According to Richter, "Many people believe that, consistent with the philosophy that access to water is a basic human right, water should be distributed free of charge" (Richter, 2017: p. 65). And as Richter explains, "For water managers, this sentiment makes it politically difficult to generate sufficient revenues while adopting a water pricing policy that keeps water distribution systems functioning" (Richter, 2017: p. 65). Furthermore, for Richter, "While the price of water should be subsidized or kept as low as possible for the poorest people in our society, everyone should understand that we must also pay for the services needed to manage our water supply" (Richter, 2017: p. 65).

\subsection{Socially Equitable Management: Ensuring Access to Drinking Water for the Poorest People}

Water is life. And ensuring people's sustainable access to water is an important part of meeting this basic need. To promote life, all conditions must be put in place to ensure that the poorest have sustainable access to drinking water.

Feedback shows that solidarity in the field of access to drinking water can be experienced at several levels. Pezon and Canneva share the experience of municipalities in France in the following terms: "while water from standpipes is free, access to the home is paid for by each subscriber" (Pezon \& Canneva, 2009: p. $30)$.

Thus, consumers who can afford to be connected to domestic water supply networks take care of those who cannot and who have to go to public water points, standpipes. Another aspect of solidarity is that exercised by city dwellers towards rural people. In this sense, Pezon and Canneva also show that "solidarity is then exercised from the wealthy urban dwellers to the most modest: it is the private service subscriptions that must remunerate the industrial and financial risk taken by the concessionaire" (Pezon \& Canneva, 2009: p. 30). As explained by Pezon and Canneva, "the population served at home (mainly urban) will pay a tax proportional to its consumption that will finance the provision of drinking water supply to rural communities" (Pezon \& Canneva, 2009: p. 33). It is solidarity from the urban to the rural.

As Pope Francis defends, "Access to safe drinking water is a primordial, fundamental and universal human right .... Our world has a serious social debt towards the poor. ...] This debt is partly settled by substantial economic contributions to provide drinking water and hygiene to the poorest" (François, 2015: p. 34). Thus, water pricing should not be systematic. It should be flexible to avoid excluding the poorest from drinking water. For Bonnassieux and Gangneron, "the systematization of the sale of water by volume and the increase in its price to ensure the profitability of the water service lead to increased risks of exclusion of the poorest from access to drinking water and reinforce a tendency among some users to reduce their consumption at the level of EWS and WHF, and to 
use alternative, non-potable water resources" (Bonnassieux \& Gangneron, 2011). In the same vein, Amougou argues that "people with zero purchasing power should have access (to drinking water) through special contractual clauses guaranteed by the public authority" (Amougou, 2002: p. 161).

The social dimension of water pricing should be emphasized. According to Richter, "One aspect of water conservation that is rightly attracting much attention at present is water pricing. Unsurprisingly, most people will use less water if they have to pay more for it" (Richter, 2017: p. 51). For this reason, explains Richter, "many cities have introduced water pricing systems that charge urban residents more if they use larger volumes of water" (Richter, 2017: p. 51). But, notes Richter, "we must nevertheless ensure that this pricing policy does not make water unaffordable for the poorest members of our society" (Richter, 2017: p. 51). Similarly, Odoulami, Gbesso, and Hounguèvou argue that: "drinking water should be made available to the rural population without compensation for the preservation of their health, which is essential for the economic development of the commune" (Odoulami, Gbesso, \& Hounguèvou, 2013: p. 112). In reality, it is a matter of public health; and it is in the general interest of the nation that everyone has access to drinking water.

Richter notes that, "water shortages can be deadly for many poor people living in developing parts of the world, as they no longer have direct access to safe drinking water supplies" (Richter, 2017: p. 16). Water shortages or pollution have a negative impact on the lives of the poorest people. As Richter explains, "When local water sources dry up or become polluted, many people-often women and children-are forced to walk long distances to reach other water sources. This takes a heavy toll on their health and their ability to participate in other tasks or attend school" (Richter, 2017: p. 16).

The impact of water scarcity on the poor is enormous. As Richter explains, "The decline in the ability of many poor families to produce their own food due to water scarcity leads to mass migration out of water-scarce areas" (Richter, 2017: p. 16). Richter discusses other types of consequences. According to Richter, "at its worst, water scarcity leads to bankruptcy, divorce, suicide, and the fracturing of formerly cohesive communities" (Richter, 2017: p. 16).

No one should be excluded from access to safe drinking water. As Richter argues, "No one should lose their right or access to water in the transition to a new allocation system, whether because of inability to pay, illiteracy, religious or cultural beliefs, or other reasons" (Richter, 2017: p. 88). Access to safe drinking water is a fundamental right; water is a basic need. According to Richter, "Basic human needs for water should be guaranteed as a compulsory right, whether they are the needs of a community or those of an individual" (Richter, 2017: p. 88). Water is a basic need not only for drinking and domestic needs but also for essential public services. Thus, as Richter argues, "other priorities that may benefit from mandatory entitlements are for water needed to ensure essential public services, such as hospitals, firefighting organizations, schools, power generation facilities, and other socially valued services" (Richter, 2017: p. 88). 


\subsection{Environmentally Sustainable Management: Conserving Water}

Taking into account the ecological dimension of management aims to ensure that enough water remains in the country's freshwater ecosystems to maintain their good health. According to Prosper-Laget, "water management certainly requires financial means, advanced technology and the responsibility of the public authorities and all users". Prosper-Laget poses the question in the following terms: "Is the lesson of our cultural history not that of a more respectful behaviour towards Nature?" (Prosper-Laget, 2001). He therefore invites us to remember that water, in particular, is a wonderful gift of life (Prosper-Laget, 2001). Richter asks: "How much water do we want to leave in our rivers to support fishing, make recreational activities possible, preserve the beneficial services that ecosystems provide, or support aesthetic or spiritual values?" (Richter, 2017: p. 79). For Richter who quotes Petre H. Gleick, "it is the use of water that supports the capacity of human society to sustain and prosper in the indefinite future without undermining the integrity of the hydrological cycle or the ecological systems that depend on it" (Richter, 2017: p. 77).

Problems of ecological balance of water supplies

There are problems with environmental impacts on water supplies. According to Richter, "There is no telling sign of the widespread and chronic mismanagement of our planet's water supplies than the current depletion of aquifers and lakes" (Richter, 2017: p. 35). As Richter explains, "Much of the water accumulated over thousands of years, which represents the legacy of several past generations, is now being depleted within a few decades. It's a bit like burning down your house to stay warm a little longer" (Richter, 2017: p. 35). There is a balance that must be maintained so that water supplies continue to provide the ecological service they do. For Richter, "It appears that ecological thresholds for aquifers and lakes are even more sensitive than those for rivers. These water sources are at the centre of a dichotomous dilemma: they can contain and store huge volumes of water, but small drops in their water levels can cause significant ecological damage" (Richter, 2017: p. 79). As Richter notes, "A growing body of evidence from around the world suggests that when the daily flow of water in a river is reduced by more than about $20 \%$, it is very likely that the ecological health of the river-the river ecosystem-will suffer" (Richter, 2017: p. 79).

Pockets of water are interconnected. Rivers function as communicating vessels. In this sense, Richter explains that "many surface water bodies constantly bring water to rivers and springs, providing a generally cooler, perennial and crucially important flow of water during the dry season and droughts" (Richter, 2017: p. 80). The finding is that, as Richter explains, "when groundwater levels drop due to overpumping, the water supply from the aquifer to rivers and streams may disappear" (Richter, 2017: p. 80).

To this end, Richter argues that "Environmental scientists should also be involved in designing strategies for good watershed management, or for the ecological functioning of freshwater ecosystems" (Richter, 2017: pp. 65-66). Richter 
gives the example of communities using the waters of the Colorado, Jordan, Cauvery and hundreds of other water-stressed rivers and aquifers around the world. For Richter, these communities are experiencing serious difficulties for two reasons. The first reason, according to Richter, is that "they have consumed their available water faster than it could be replenished regularly by rain and snow". And the second reason Richter suggests is that: "they have not shown restraint or have not carried out enough regulatory controls, or are overwhelmed by the day-to-day struggle for life to prevent this from happening" (Richter, 2017: p. 20).

Possible solutions

Solutions can be found locally and globally. At the local level, rivers are surrounded by myths, rituals and symbols. Thus, for Alissoutin, "water being sacred, it must be protected" (Alissoutin, 2014: p. 2). Local practices exist to protect watercourses. As Alissoutin explains, "with regard to ponds, for example, village environmental protection techniques have mainly involved maintaining the vegetation cover and determining a protection perimeter around the water point" (Alissoutin, 2014: p. 2). Furthermore, as Alissoutin shows, "To slow down the evaporation of ponds and, on the contrary, encourage the accumulation of water, two techniques are implemented. One is passive and consists of prohibiting tree cutting around ponds, the other is active and consists of reforestation" (Alissoutin, 2014: p. 2). At the global level, according to Michel Serres, a contract with nature should be established. According to Serres, "once again, we have to rule on the defeated, writing down the rights of those who have none" (Serres, 1992: p. 63). Serres refers to the right of symbiosis. He explains it in the following terms: "The parasite takes everything and gives nothing; the host gives everything and takes nothing. The right of control and ownership is reduced to parasitism. On the contrary, the right of symbiosis is defined by reciprocity: as much as nature gives to man, so much must man give back to nature, which has become a subject of law" (Serres, 1992: p. 67).

\section{Culture as a Driving Force for Sustainable Development in the Water Sector}

Taking into account the local culture of the beneficiaries in the field of water is a necessity. As Brelet explains, in terms of improving access to drinking water, "good practices combine the modern utilitarian logic of engineering and the quantitative data gathered by the water sciences with the ethical values conveyed by local spiritual traditions" (Brelet, 2004: p. 36). Similarly, Pope Francis in his encyclical letter Laudato argues that " $[t]$ here is a need to have recourse ... to the diverse cultural riches of peoples, to art and poetry, to the interior life and spirituality" (François, 2015: p. 64). The Pope notes that "Unfortunately, water is being wasted. This shows that the problem of water is in part an educational and cultural issue" (François, 2015: p. 35). Similarly, according to the Rio Declaration, Principle 22, "Indigenous peoples and communities and other local com- 
munities have a vital role to play in environmental management and development through their environmental knowledge and traditional practices" (United Nations, 1992). The Bruntland report goes further, stating that "local communities should have the final say in decisions about resource use in their areas" (Bruntland, 1987).

The fruitful articulation between culture and development applied to the water sector is reviving the debate on taking culture into account for sustainable development. For Diop, "the concept of development in which the local level, populations, their values and symbolic references as well as their socio-cultural anchoring would henceforth be taken into account, replaces the concept of global development". According to the author, "In contrast to top-down development, these different theories advocate a conception of development that privileges the role of local populations and resources" (Diop, 2016). As Mboua argues, "it is legitimate in the action of development for progress that human beings understand the cultural heritage they have received". (Mboua, 2014: p. 80). As explained by Teisserenc, "The experience of local development policies shows that culture is not seen as what gives meaning to development, but as an integral part of the development process, in the same way and on the same level as the other dimensions (economic and social) that structure and organize the life of a human community settled in a territory". For him, "Culture is also an excellent means of opening up and encouraging initiative and creation. This aspect is essential to the success of local development policies". According to the author, "Culture is no longer [...] the finality of development. It is increasingly at the very heart of the mechanisms generated by new forms of economic and social development in a territory" (Teisserenc, 1997: p. 109). Culture can become a genuine concept of development if it is based, as Renaud Sainsaulieu explains, on "a process of creativity within the organization based on the recognition of differences, the emergence of new identities and the collective formulation of projects" (Sainsaulieu, 1987). Thus, as Diop (2016) argues, “it is necessary to think of development generated from within, conceived by the African genius who relies on a rich historical tradition of teaching and dictated for the needs of the continent" (Diop, 2016: p. 116). It is therefore urgent to restore the socio-historical and cultural values of the African continent.

\section{Conclusion}

At the end of this reflection, a contribution to the debate on the articulation between culture and sustainable development, some achievements are worth noting. Applied to the hydraulic sector, the management of hydraulic works for access to water, this study has shown that the local culture of the beneficiaries must be taken into account in each of the dimensions of sustainable development. Water is life. And to protect the value of life that is water, all sacrifices are justified so that everyone can have access to water and so that future generations can also benefit from it in quantity and quality. Economically speaking, water, 
although free in nature, has a cost and a price. Water must be paid for the continuity of the service. This payment also has a social impact and is aimed at giving the poorest access to water. Thus those who have the financial means must pay for water so that water can ensure its vocation which is to sustain life; water is life. From an environmental point of view, water extraction must ensure that the ecological service provided by water reserves is sustainable. In short, this consideration of culture in development in the water sector reopens the debate on the important place that culture must occupy in the process of sustainable development.

\section{Conflicts of Interest}

The authors declare no conflicts of interest regarding the publication of this paper.

\section{References}

Alissoutin, R. L. (2014). La négation du pouvoir local dans les politiques de l'eau en Afrique. Mieux vendre. Paris: Initiatives locales et négociations internationales. http://www.inter-reseaux.org/IMG/pdf/allissoutin_eau.pdf

Allemand, S. (2007). Les paradoxes du développement durable. Paris: Le Cavalier Bleu.

Amougou, J. P. (2002). L'eau, bien public, bien privé: L'Etat, les communautés locales et les multinationales. L'eau, patrimoine commun de l'humanité (pp. 147-170). Louvainla-Neuve: Centre Tricontinental.

Bonnassieux, A., \& Gangneron, F. (2011). Des mini-réseaux d'eau potable: Entre enjeux politiques et arrangements locaux. Le cas de la commune de Djougou au Bénin. (D. B. Supérieur, Éd.). Mondes en développement, 155, 77-92. https://doi.org/10.3917/med.155.0077

Brelet, C. (2004). L'eau et la gouvernance: Meilleures pratiques éthiques. COMEST. Paris: UNESCO Edition. http://www.pseau.org

Bruntland, G. H. (1987). Notre avenir à tous. Oxford: Oxford University Press.

Bujo, B. (1992). La conception négro-africaine de la nature et le problème de l'écologie. Ethique et natures (pp. 149-159). Genève: Labor et Fides.

Bujo, B. (2007). Culture africaine et développement: Un dialogue nécessaire 3. Finance \& Bien Commun, 28-29, 40-45. https://doi.org/10.3917/fbc.028.0040

Côté, M.-C. (2006). La gestion de l'eau au Québec: Notre responsabilité vis-à-vis des générations futures. Mémoire de Maîtrise, Rimouski: Université du Québec.

Diop, A. S. (2016). Les théories africanistes du développement. Entre déconstruction et travers idéologiques. Paris: L'Harmattan.

Etounga-Manguelle, D. (1993). L'Afrique a-t-elle besoin d'un programme d'ajustement culture? Ivry: Editions Nouvelles du Sud.

François, P. (2015). Lettre encyclique Laudato Si. Sur la sauvegarde de la maison commune. Lomé: Saint-Augustin d'Afrique.

Mboua, E. (2012). Fondement des valeurs éthiques africaines. L'idée des biens fondamentaux chez Finnis. Paris: L'Harmattan.

Mboua, E. (2014). Ethique du développement pour le progrès en Afrique. Paris: L'Harmattan.

Meadows, D., Meadows, D., Randers, J., \& Behrens, W. I. (1972). Halte à la croissance? 
Rapports sur les limites de la croissance (Delaunay, J., Trad.) Paris: Fayard.

Mill, J.-S. (1953). Principes d'économie politique. Paris: Dalloz.

Morin, E. (2002). Pour une politique de l'humanité. Libération. http://www.liberation.fr

United Nations (1992). Rapport de la conférence des Nations Unies sur l'environnement et le développement, Rio de Janeiro, 3-14 juin 1992 A/CONF.151/26 (Vol. I). Rio de Janeiro. https://doi.org/10.18356/801f0ab5-fr

Odoulami, L., Gbesso, F., \& Hounguèvou, S. (2013). Qualité de l'eau de consommation et maladies hydriques dans la commune de Ze (Benin). Revue de Géographie Tropicale et d'Environnement, 2, 104-113.

Payen, G. (2013). De l'eau pour tous! Abandonner les idées reçues, affronter les réalités. Paris: Armand Colin.

Pellaud, F. (2011). Pour une éducation au développement durable. Versailles: éd. Quae. https://doi.org/10.3917/quae.pella.2011.01

Pezon, C., \& Canneva, G. (2009). Petites communes et opérateurs privés: Généalogie du modèle français de gestion des services d'eau potable. Espaces et sociétés, 139, 21-38. https://doi.org/10.3917/esp.139.0021

Prosper-Laget, V. (2001). Les rapports de l'homme à l'eau ou les mythes retrouvés. Eaux sauvages eaux domestiques. Hommage à Lucette DAVY (p. 342). Provence.

Richter, B. (2017). La crise de l'eau, guide pratique pour une gestion durable (Evrard, O., Trad.) Louvain-la-Neuve: De Boeck Supérieur.

Sainsaulieu, R. (1987). Sociologie de l'organisation et de l'entreprise. Paris: Dalloz/FNSP.

Serres, M. (1992). Le contrat naturel. Paris: Flammarion.

Singleton, M. (2010). Histoires d'eaux africaines. Essais d'anthropologie impliquée. Louvain-La-Neuve: Bruylant-Academia s.a.

Teisserenc, P. (1997). Le développement par la culture. L'Homme et la société, 125, 107-121. https://doi.org/10.3406/homso.1997.2902 